\title{
Movimentos sociais na América Latina: elementos para uma abordagem comparada
}

Social movements in Latin America:
elements for a comparative approach

Camille Goirand

A partir do fim da década de 1960, em todo o mundo ocidental, inclusive na América Latina, multiplicaram-se movimentos sociais cuja "novidade" foi frisada pela sociologia. Na Europa, nos Estados Unidos e na América Latina, alguns anos após 1968, esses "novos movimentos sociais" começaram a contestar a ordem social, e depois, a partir do fim da década de 1970 e início dos anos 1980, começaram a participar da oposição aos regimes autoritários, na América Latina mas também na Europa oriental. Após o fracasso da maioria das guerrilhas marxistas-leninistas, ${ }^{1}$ a Igreja Católica da Teologia da Libertação fomentou e apoiou mobilizações que, afirmando a dignidade dos pobres e dos humildes frente ao poder político, contribuíram para estruturar progressivamente as oposições aos

Camille Goirand é professora titular de ciência política do Instituto de Estudos Políticos de Lille e pesquisadora do Centro de Pesquisa em Administração, Política e Sociedade (Ceraps), na Universidade Lille 2, França (cgoirand@wanadoo.fr).

Artigo recebido em 26 de junho de 2009 e aprovado para publicação em 27 de agosto de 2009.

Tradução de Clóvis Marques.

Est. Hist., Rio de Faneiro, vol. 22, n. 44, p. 323-354, julho-dezembro de 2009. 
regimes militares. Surgidos durante a liberalização da década de 1980, esses movimentos muito diversos estruturaram-se, numa primeira etapa, fora do contexto oferecido pelos partidos políticos e os sindicatos tradicionais, obedecendo a lógicas apresentadas como "novas". Correspondem a essa categoria os "novos movimentos sociais", movimentos tão diversos quanto, por exemplo, o Movimento dos Sem Terra, criado no Brasil em 1979 para reivindicar a generalização do acesso à terra através de uma reforma agrária; o movimento ecologista no Equador, onde a associação Acción Ecológica opõe-se desde 1987 às concessões feitas pelo Estado às grandes empresas para a exploração do petróleo, apoiando-se, nesse sentido, numa estratégia de advocacy internacional, assim como na construção de redes transnacionais; ${ }^{2}$ no México, o Movimento Urbano Popular (MUP), o qual, após sua criação em 1981 e a fundação da Assembleia de Bairros (Asamblea de Barrios) na Cidade do México, promoveu mobilizações em prol da habitação, particularmente ativas e mediatizadas entre 1985 e 1988, em torno da figura paródica de SuperBarrio; as organizações piqueteras da Argentina, como a Federación de Tierra, Vivienda y Habitát ou a Unión de Trabajadores Desocupados (UTD), ambas criadas em 1997, quando a crise econômica se agravava, tendo a segunda participado das primeiras obstruções de rodovias após o fechamento da usina da Yacimientos Petrolíferos Argentinos na cidade de General Mosconi, na província de Salta, no norte do país; as mobilizações indigenistas, estruturadas na Confederación de Nacionalidades Indigenas de Ecuador (CONAIE), movimento social independente criado em 1986, ou ainda a Central Indígena del Oriente Boliviano (CIDOB), que foi criada em 1982 na Bolívia e participou das mobilizações eleitorais em favor do atual presidente Evo Morales, ao lado da Confederación Sindical Única de Trabajadores Campesinos de Bolivia (CSUTCB), organização de trabalhadores rurais e produtores de coca criada em 1979; ou finalmente, no Brasil, o Movimento Nacional dos Catadores de Materiais Recicláveis, que desde o seu surgimento em 1985, em São Paulo, exige o reconhecimento dos direitos e da dignidade daqueles que encontram um meio de subsistência nos depósitos de lixo...

Que há de comum, então, entre todos esses "novos movimentos sociais"? E por que se pretendeu enxergar neles uma "novidade"?... A comum aspiração à mudança social e política em nada os distingue de movimentos sociais mais clássicos e mais antigos, como os movimentos operários, que em sua época também foram portadores de valores e projetos alternativos de sociedade. Para muitos analistas, a especificidade da contestação pode ser identificada em outro ponto: a associação entre, por um lado, essa aspiração à mudança social e política, e, por outro, uma estrutura organizacional frouxa, fluida, fragmentada e instável. A "novidade" desses movimentos, destacada por muitos autores, decorre sobretudo da ausência de um envolvimento de classe claramente definido, da au- 
sência de estruturação ideológica unificada, da pluralidade dos valores e representações da ação, da prioridade conferida aos discursos da justiça e da dignidade, associadas à definição de objetivos pragmáticos obedecendo a uma lógica às vezes setorial, à descoberta de novos canais de participação política, à descentralização ou fragmentação de organizações extremamente diversas. ${ }^{3} \mathrm{Na}$ realidade, a categoria "novos movimentos sociais" foi aplicada a mobilizações muito heterogêneas, manifestando-se em ambientes políticos e sociais de uma extrema diversidade. No continente latino-americano, a partir do fim da década de 1970, a contestação desenvolveu-se quase sempre frente a regimes autoritários e repressivos mas em processo de liberalização, num contexto de desigualdades sociais crescentes e de crise econômica de grande amplitude. Além disso, o fracasso das oposições armadas, associado a um processo de reavaliação do reformismo e da socialdemocracia, ${ }^{4}$ foi acompanhado de uma recomposição das esquerdas e dos sistemas partidários, abrindo para a expressão da contestação decorrente dos movimentos sociais um espaço político que antes não existia.

$\mathrm{Na}$ observação e análise desses movimentos sociais, as perspectivas adotadas a partir da década de 1970 pelas ciências sociais da América Latina apresentam algumas especificidades, distinguindo-se em parte das que então foram preferidas na América do Norte, mas também no Velho Continente. A partir da década de 1960, com efeito, a sociologia das mobilizações nos Estados Unidos e na Europa passou por um vivo debate, contrapondo a abordagem pela mobilização dos recursos à abordagem pelos "novos movimentos sociais", presente sobretudo na Europa. ${ }^{5}$ Mas em ambos os casos generalizou-se em período mais recente o questionamento em torno da análise estratégica e da racionalidade dos atores ${ }^{6}$ da mobilização dos recursos ${ }^{7}$ ou ainda da estrutura organizacional dos movimentos sociais. ${ }^{8} \mathrm{Na}$ América Latina dos anos 1980 e 90, a pesquisa sobre os movimentos sociais mostrou-se particularmente rica, abordando o objeto de uma perspectiva frequentemente distinta da europeia ou norte-americana. Na maioria dos casos, a atenção voltou-se para a questão dos valores e demandas de mudança social, estruturando-se o debate em torno do sentido adquirido por essas mobilizações, para as sociedades e as democracias em construção.

Desse modo, a abordagem pelos "novos movimentos sociais" mostrou-se dominante no continente latino-americano. Alguns autores, como Maria da Glória Gohn, não hesitam em falar da existência de um "paradigma latino-americano", oposto ao modelo "norte-americano" da mobilização dos recursos. ${ }^{9}$ A observação das mobilizações, construída a partir de casos norte-americanos ou europeus, ressaltou a importância das características organizacionais dos movimentos sociais, ainda que "novos" e construídos em torno de valores. De sua par- 
te, a sociologia política voltada para os casos latino-americanos, observados tanto por pesquisadores originários dessas sociedades quanto por seus colegas latino-americanistas da Europa ou da América do Norte, estruturou seu olhar sobretudo em questionamentos e questões conhecidos da abordagem pelos "novos movimentos sociais". ${ }^{10}$ Por um lado, a atenção voltou-se prioritariamente para a relação entre a mudança sociopolítica e esses movimentos, e por outro o próprio debate revelou-se inseparável dos posicionamentos políticos e do engajamento dos que o conduziam, mostrando-se de difícil identificação e mesmo inexistente a fronteira entre sociologia e ação política.

A propósito da América Latina, a análise das organizações despertou menos interesse que a dos discursos, das reivindicações e demandas, remetendo de maneira mais ampla ao significado político e social desses movimentos. Essas diferenças não podem ser atribuídas unicamente às especificidades dos casos observados, na medida em que a ação coletiva de contestação repousou, tanto no mundo ocidental quanto na América Latina, em organizações de características comparáveis: fragmentárias, territorializadas e associativas. ${ }^{11}$ Desse modo, a contestação liderada pelos movimentos sociais "novos" construiu-se o mais das vezes fora dos espaços tradicionais da mobilização, notadamente os do trabalho, aqui como lá. Muito debatidas na política, essas questões foram mais objeto de afirmações de princípios que de pesquisas sistemáticas, no caso da América Latina. ${ }^{12}$

Numa primeira etapa, o objetivo deste artigo consistirá em lembrar as trajetórias históricas, assim como as características dos movimentos sociais ditos "novos" que se afirmaram na América Latina a partir da década de 1970. Serão evocadas em seguida as principais perspectivas adotadas pela sociologia política para analisar essas mobilizações. Finalmente, serão propostos alguns elementos de reflexão sobre os caminhos que uma renovação dos quadros de análise desses movimentos sociais poderia tomar. Em particular, será evocado o debate levantado pela institucionalização atual dos movimentos sociais na América Latina, assim como seus limites, que permitem frisar a urgência da renovação dos modelos hoje disponíveis para observar os movimentos sociais desse continente. Revisitar a maneira como eles foram pensados e observados desde a década de 1970 constitui, do nosso ponto de vista, uma démarche essencial e necessária para a análise e a compreensão do ciclo de protesto instaurado na região desde meados da década de 1990: piqueteros da Argentina, movimentos indígenas da Bolívia e do Equador, Movimento dos Sem Terra no Brasil, oposição transnacional ao projeto de Zona de Livre Comércio das Américas ou ao Plano Puebla Panamá, mobilizações pós-eleitorais e oposição à abertura do capital da Pemex no México, regionalismos da Bolívia, exigência de investigação do passado na Argentina e no Chile... diferentes casos de mobilização para cuja observação parece-nos útil questionar-se sobre os modelos de análise disponíveis. 


\section{Os "Novos Movimentos Sociais" na América Latina: uma eclosão constante}

\section{O "basismo" na América Latina das décadas de 1970 a 1990}

$\mathrm{Na}$ América Latina, frequentemente se tem preferido a expressão "movimento popular" a "novos movimentos sociais" para se referir às mobilizações. Designando dessa forma ao mesmo tempo organizações de classe média, operárias e camponesas, bem como as dos habitantes dos bairros desfavorecidos, militantes e pesquisadores referiam-se à construção de uma malha das sociedades "vinda de baixo". Assim foi que se preferiu o conceito de "popular" aos de "proletariado" e "povo", pois remete menos a uma representação das sociedades em "classes", definidas por uma posição no sistema de produção, do que a sua estruturação em termos de poderes, mas também de representações. Se "popular" às vezes serve como sinônimo de "povo", é sobretudo no sentido de "pobres", ocupando uma posição baixa na hierarquia social dos poderes e rendas; a isto remete explicitamente a expressão inglesa "grass-root". A expressão "movimento social de base" designa portanto mobilizações conduzidas principalmente por cidadãos pobres, às vezes camponeses, cujas reivindicações extremamente heterogêneas se organizaram em torno da questão das condições de vida, do acesso aos serviços públicos e dos direitos sociais. ${ }^{13}$

A emergência do "basismo" na América Latina inscreveu-se num duplo processo. Em primeiro lugar, a liberalização dos sistemas políticos a partir do fim da década de 1970 possibilitou a expressão das demandas. No Cone Sul do continente, o lentíssimo desengajamento político dos militares brasileiros, a partir do extremo fim da década de 1970, foi ritmado pela anistia dos exilados em agosto de 1979, a reintrodução do pluripartidarismo em novembro de 1979, a introdução da eleição direta dos governadores em 1982, a chegada de um civil à presidência em 1985 e finalmente a adoção da Constituição da Nova República em 1988. Na Argentina, a junta militar precipitou seu próprio fim ao decidir a ocupação das ilhas Malvinas, que resultou numa capitulação em junho de 1982, seguida de um rápido processo de transição: a legalização dos partidos políticos em agosto de 1982 foi seguida de eleições gerais em outubro de 1983, levando à presidência o radical Raúl Alfonsín. No Chile, depois de longos anos de uma repressão feroz, o governo Pinochet organizou em outubro de 1988 o plebiscito previsto pela Constituição de 1980 , sobre sua própria confirmação no poder. Aceitando o veredito das urnas, Augusto Pinochet deixou a presidência, ao passo que os partidos políticos eram novamente autorizados e Patricio Aylwin vencia as eleições presidenciais em dezembro de $1989 .{ }^{14}$ Mais ao norte, o processo de abertura foi iniciado num período mais tardio. No México, o lento processo de liberalização política e estabelecimento do pluralismo partidário teve início no 
fim da década de 1980, particularmente com a criação do PRD em 1989, o processo de "descentralização participativa" empreendido a partir de 1995 e depois a reforma constitucional de 2001. ${ }^{15} \mathrm{Na}$ América Central, no caso das "transições insurgentes", a mudança institucional foi acompanhada de uma fortíssima mobilização e de um conflito armado prolongado e generalizado. ${ }^{16} \mathrm{Em}$ toda parte, esses processos de abertura institucional se acompanharam de mobilizações populares de massa, que foram carreadas por uma explosão das expectativas e se caracterizam pela heterogeneidade das práticas e organizações que as conduziram.

Em segundo lugar, paralelamente à multiplicação dos "novos movimentos sociais", a exemplo dos mencionados acima, desenrolaram-se mobilizações de rua de alcance nacional e diretamente ligadas à mudança política e às exigências de democratização das instituições políticas. Assim foi que os argentinos se manifestaram nas ruas de Buenos Aires em dezembro de 1982 para exigir eleições gerais, enquanto milhões de brasileiros desciam às ruas das principais cidades do país para exigir eleições presidenciais diretas, aos gritos de "Diretas já!", em abril de 1984. No Uruguai, as jornadas nacionais de protesto de julho e agosto de 1984 foram seguidas de uma greve geral em dezembro do mesmo ano. No Chile, as jornadas de protesto nacional e de greves gerais provocaram a instauração e a suspensão regulares do estado de sítio entre 1983 e 1986, e em seguida numerosas manifestações de rua viriam apoiar a campanha pelo "não" no referendo de 1988. Tal como nos casos observados por Anthony Oberschall, a conjugação da disseminação das exigências ligadas ao respeito dos direitos humanos ou à justiça social aos processos de reforma institucional reforçou as oposições e as mobilizações, "possibilitando a emergência de queixas há muito recalcadas e de exigências que foram muito além daquilo que as autoridades inicialmente previam". ${ }^{17}$

As demandas que se manifestaram no contexto dessas aberturas políticas repousaram numa reconstrução do quadro de compreensão e interpretação das desigualdades sociais e políticas, carreada pelos movimentos "de base" que redefiniram as privações de direitos sociais como discriminações ilegítimas. ${ }^{18}$ Conflitos em torno do sentido a ser conferido às desigualdades sociais e políticas, essas mobilizações contribuíram para um trabalho de reinterpretação das injustiças. A ação coletiva de base repousou, por um lado, na politização de questões concretas e imediatas como a habitação e as infraestruturas urbanas; e, por outro, na percepção da posição comum dos grupos populares frente às necessidades ou carências, logo, na construção de um "quadro de injustiças" através da conscientização da ilegitimidade da privação. O conceito de "expoliação urbana", então proposto pelo brasileiro Renato Boschi, designa a injustiça da posição ocupada nas cidades pelas populações desfavorecidas, cuja marginalidade é associada à percepção da ilegitimidade da privação de direitos. ${ }^{19}$

Alguns elementos de contextualização histórica permitirão aqui fornecer esclarecimentos sobre o processo histórico de construção desses movimen- 
tos. A partir do extremo fim da década de 1970, em todo o continente, movimentos de contestação se organizaram nos meios populares, em diferentes setores: creches associativas, cooperativas alimentares ou sopas populares, quase sempre organizadas por mulheres; protesto contra a carestia no Brasil; reivindicação de acesso a tratamentos médicos; oposição à política de destruição das favelas; reivindicação de reconhecimento da propriedade da terra, por parte dos habitantes de lotes urbanos irregulares ou dos indígenas no meio rural, ou ainda da parte do Movimento dos Sem Terra (MST) a partir de 1981 no Brasil. Nas classes médias, outros movimentos deram ênfase a questões diferentes, como os movimentos de defesa dos direitos humanos nos países do Cone Sul, com a campanha "Tortura, nunca mais!", promovida a partir de 1985 por diferentes associações de defesa dos direitos humanos no Brasil, ou as reivindicações de julgamento dos responsáveis por violações dos direitos humanos na Argentina após a interrupção dos processos em $1986 ;{ }^{20}$ os movimentos feministas que deram prioridade aos direitos de reprodução e à igualdade em política; ou ainda o movimento de denúncia da fraude eleitoral no México...21

Vários fatores podem explicar a intensificação dessas mobilizações nesse período. Em primeiro lugar, o papel da Igreja Católica foi fundamental para a estruturação das oposições aos regimes autoritários, mas também para a formação e a politização dos jovens militantes que criaram as organizações locais de movimento social. A partir de 1968 e da conferência dos bispos latino-americanos em Medellín, que definiu a "opção pelos pobres", as Igrejas nacionais abriram um espaço de oposição política, até então inexistente. Em parte influenciadas pela Teologia da Libertação, a Igreja Católica participou da construção e depois do apoio às reivindicações das populações indígenas, no mesmo momento em que outros confirmavam seu apoio ativo a certas guerrilhas, como o cardeal Ernesto Cardenal na Nicarágua sandinista depois de 1979. Tanto nas favelas das grandes cidades quanto nos mais desfavorecidos meios rurais, a politização dos militantes foi suscitada por padres, que contribuíram para estruturar suas primeiras ações. ${ }^{22}$ As comunidades eclesiais de base (CEB), espaços de convergência e discussão organizados por padres próximos da Teologia da Libertação, constituíram espaços de socialização e politização que contribuíram amplamente para destacar os valores de participação, respeito e justiça, muito presentes no "basismo" da década de 1980, especialmente nos movimentos de bairro, como indicava Paulo Krischke en 1991.23

Em segundo lugar, a conjugação da liberalização progressiva de uma parte dos regimes autoritários, do esgotamento das ideologias e dos grupos revolucionários que defendiam a luta armada, assim como da crise econômica brutal da década de 1980 explica que as mobilizações tenham inaugurado novas formas de organização, ao mesmo tempo em que apresentavam uma forte heterogenei- 
dade. A partir da década de 1980, essas transformações traduziram-se inicialmente na fragilização e logo no desmantelamento dos corporativismos de Estado, que por muito tempo haviam representado instrumentos de enquadramento das mobilizações nas mãos dos regimes nacional-populares. Com a fragmentação da paisagem sindical, associada à generalizada queda do número de filiados, "a centralidade do trabalho organizado como ator político na América Latina foi minada", segundo Philip Oxhorn. ${ }^{24}$ Paralelamente, as associações de solidariedade e ajuda mútua, tanto microlocais quanto nacionais, tornaram-se canais importantes de participação social e política para as classes médias e populares, muitas vezes apoiadas por profissionais liberais, como assistentes sociais e educadores, advogados e médicos.

A respeito desse período, Susan Eckstein frisou a coexistência de repertórios de ação coletiva muito diferentes. Ela distingue, por um lado, as revoltas da fome, os saques e invasões de terras, e, por outro, as greves organizadas por grandes sindicatos, os grandes comícios políticos e até a mobilização em novos partidos de esquerda, como o PT brasileiro e o PRD mexicano. Para explicar essa oposição, Susan Eckstein considera que as formas assumidas pela contestação dependeram, na década de 1980, do nível de industrialização, da estrutura sindical e das desigualdades sociais, assim como do grau de abertura do sistema político, em cada país do continente. Ela demonstrou, assim, de que maneira a politização das reivindicações variou em função da posição social ocupada pelos grupos mobilizados. Desse modo, as classes médias e superiores foram portadoras de reivindicações institucionais e exigências de democratização política, ao passo que as classes populares deram prioridade às questões econômicas e às condições de vida. Essas diferenças traduziram-se nos repertórios de ação coletiva disponíveis a esses diferentes grupos. A partir dos exemplos da Bolívia, do Peru e do México, Susan Eckstein indica que os grupos populares, dominados do ponto de vista econômico e social, tenderam mais que os outros a organizar a contestação "na rua", na medida em que sua capacidade de influenciar a política repousava mais em mobilizações em campo que em mediações formais partidárias, por exemplo. ${ }^{25}$ Posicionando-se em desacordo com a perspectiva de classe adotada por Susan Eckstein, David Slater frisava, todavia, certas especificidades das lutas conduzidas pelos grupos populares na América Latina, conferindo uma dimensão fortemente territorial e social ao engajamento democrático, para além da arena eleitoral. ${ }^{26}$

\section{A contestação da década de 2000}

Com a liberalização dos regimes políticos, bem como das economias, não só as questões em jogo mas também o contexto das mobilizações se redefi- 
niram. É efetivamente o que frisam certos trabalhos coletivos publicados desde 2000. Com Susan Eckstein, mais uma vez, podemos diferençar as dinâmicas de erosão das que assinalam o reforço da contestação. Aquelas dizem respeito sobretudo ao movimento operário, que prosseguiu declinando, como indica a queda do número de greves na década de $1990 .{ }^{27}$ Enquanto as mobilizações continuam a se afastar da esfera do trabalho, a se territorializar e a se construir em torno da afirmação de identidades culturais, ${ }^{28}$ diminui a frequência das invasões de terras no meio urbano e a Igreja Católica efetua um retorno à fé e à ação religiosa. Simultaneamente, contudo, outras mobilizações parecem obedecer a dinâmicas diferentes e ganhar força: os repertórios de ação coletiva continuam a se enriquecer, com as longas marchas pacíficas em direção às capitais, como a dos opositores do ALCA, ${ }^{29}$ que convergiu para Quito em novembro de 2002, ou a dos neozapatistas em direção à Cidade do México em 2001; os movimentos de defesa dos direitos não arrefecem no Chile, e na Argentina conseguiram a anulação das leis de anistia a partir de 2003; as organizações indigenistas mostraram sua capacidade de mobilização na Bolívia desde a eleição de Evo Morales para a presidência em 2006; a contestação das classes políticas abalou os regimes políticos argentino em 2001 e equatoriano em 2004 e em 2007, aos gritos de "Que se vão todos eles!", enquanto os mexicanos ocuparam as praças públicas a partir de julho de 2006 para contestar o resultado da eleição presidencial ou a legitimidade do governador do estado de Oaxaca...

A década de 2000 parece confirmar a tendência identificada por Susan Eckstein. Não só a contestação promovida pelas classes populares não se extinguiu e continua a marcar a vida política em vários países do continente, como parece inclusive ampliar-se, apoiando-se num repertório maior de ações coletivas. Grupos sociais até então pouco mobilizados rapidamente impuseram sua presença na política, tendo em alguns casos adentrado a cena política nacional. Na Argentina, ações espetaculares chegaram a ser promovidas pelos piqueteros, que bloquearam estradas em várias ocasiões, inicialmente, a partir de 1995 e 1996, em várias províncias situadas a nordeste mas também na Patagônia, e posteriormente, em novembro de 2000, quando duas federações de associações de bairro do subúrbio de Buenos Aires bloquearam a rodovia ${ }^{\circ} 3$ durante um mês, em La Matanza, principal acesso rodoviário à capital pelo oeste. Os cacerolazos de 2001 e em seguida os novos bloqueios de estradas promovidos pelos trabalhadores rurais de Campo em 2008 apoiam-se nessa prática da ação coletiva, que conjuga ações espetaculares a reivindicações políticas claras e explícitas, como observa Denis Merklen: oposição às políticas liberais de reforma do Estado, exigência de ajuda social, vontade de resistência ao acelerado empobrecimento da população argentina. ${ }^{30}$

Simultaneamente, mobilizações mais antigas se fortalecem, notadamente no terreno da defesa dos direitos humanos. Na Colômbia, num contexto 
em que o conflito se complicou e degradou, as mobilizações pela paz civil favoreceram a ampliação do debate público sobre os direitos fundamentais desde o início da década de $2000 .{ }^{31} \mathrm{Na}$ Argentina e no Chile, as contínuas mobilizações dos defensores dos direitos humanos, como por exemplo as Mães da Plaza de Mayo, tiveram resposta na reabertura dos processos contra os responsáveis pelos regimes militares a partir de junho de 2005, quando o Tribunal de Recursos de Santiago revogou a imunidade de Augusto Pinochet, e em julho de 2005, quando a Corte Suprema argentina declarou "inconstitucionais" as leis de anistia de 1986 e 1987. Neste país, a reabertura dos processos a partir de 2007 foi acompanhada de muitas manifestações de rua, aos gritos de "Assassinos! Assassinos!", enquanto as dolorosas cerimônias de evocação do golpe de Estado, a cada dia 24 de março, continuam reunindo muitos participantes.

Mas a década de 2000 também foi marcada pela ampliação das mobilizações indigenistas, dando continuidade ao "despertar in dígena" da década anterior. ${ }^{32}$ Em torno de reivindicações nos terrenos da educação bilíngue, do reconhecimento cultural, do acesso aos recursos naturais e da propriedade da terra, a afirmação da indianidade constituiu o fulcro de mobilizações diversas, em vários pontos do continente, a partir das comemorações dos "Outros Quinhentos Anos" em 1992: golpe de força do Exército Zapatista de Libertação Nacional (EZLN) em San Cristobal de las Casas em janeiro de 1994, marchas de camponeses da região de Chapare em direção a La Paz, mobilização da oposição ao Plano Puebla-Panamá entre 2001 e 2004, particularmente em nome dos direitos definidos pela convenção 169 da Organização Internacional do Trabalho... são exemplos que falam do fortalecimento das mobilizações de protesto indígenas.

Para esses movimentos indigenistas, a década de 2000 foi sobretudo a da institucionalização, principalmente na Bolívia e no Equador. Nesses dois países, algumas de suas reivindicações foram atendidas, com uma nova redação das Constituições, sobrevindo por exemplo o reconhecimento do caráter "multicultural e pluriétnico" da nação equatoriana pela Constituição de 1998. Acima de tudo, os dirigentes indigenistas passaram a atuar no interior das instituições políticas representativas, desde a transformação dos movimentos em partidos políticos. Na Bolívia, assim, dirigentes indigenistas provenientes de diferentes sindicatos participaram da criação do Movimento para o Socialismo (MAS) em 1999, em nome dele fazendo campanha, exercendo seus primeiros mandatos legislativos e em seguida elegendo o atual presidente da República, Evo Morales, em dezembro de 2005. No Equador, vários membros da CONAIE exerceram funções ministeriais sob a presidência de Lúcio Gutierrez, enquanto o movimento Pachakutik decidia apresentar seu próprio candidato à eleição presidencial de 2006, Luis Macas, passando assim da ação contestatária à competição eleitoral institucionalizada. ${ }^{33}$ 
A década de 2000 parece portanto marcada ao mesmo tempo por elementos de continuidade e de ruptura, com transformações que podem parecer contraditórias à primeira vista. Por um lado, as mobilizações populares preservaram ou recuperaram forte intensidade, continuando a se apoiar em organizações territorializadas e extremamente fragmentadas. O discurso dos direitos e da justiça, se mudou de contexto, continua apoiado na afirmação de valores, como a diversidade cultural, assim como em construções identitárias, em particular no caso dos indígenas. Por outro lado, enquanto alguns movimentos se desfizeram e perderam toda combatividade, outros se unificaram parcialmente em nível nacional, não obstante sua fragmentação, como no caso dos piqueteros, ao mesmo tempo em que passavam por um processo de institucionalização bem adiantado, fosse quando seus dirigentes eram chamados a exercer funções governamentais, ${ }^{34}$ fosse quando os movimentos se transformavam em partidos políticos aptos a participar da competição eleitoral. Globalmente, portanto, os movimentos da década de 2000 apresentam muitos elementos de continuidade em relação aos que pareciam "novos" nas décadas anteriores, ao mesmo tempo em que passaram por inevitáveis transformações.

\section{Quais as "novidades"?... Sociologias dos valores e identidades}

À primeira vista, a "novidade" dos movimentos sociais surgidos na década de 1980 e depois na de 1990 residia aparentemente em características ao mesmo tempo organizacionais e ideológicas. Menos estruturados que os movimentos operários tradicionais, afirmando sua vontade de autonomia em relação ao Estado, aos partidos e à maioria dos sindicatos, eles não se apoiavam exclusivamente nas relações de produção ou de classe, contestando também a ordem social existente com base em reivindicações não materiais. A observação dessas mobilizações deu ênfase, desse modo, à sua ligação com a mudança dos valores e clivagens sociais dominantes, assim como às construções identitárias específicas por elas favorecidas. Essas duas abordagens, pelos valores e as identidades, foram amplamente adotadas pelos analistas latino-americanos.

Em primeiro lugar, alguns deles, convergindo com as perspectivas abertas por Ronald Inglehart, frisaram o estreito vínculo entre os processos de transformação em profundidade das sociedades e as especificidades dos modos de organização dessas mobilizações, às vezes instáveis, frequentemente localizadas e fragmentárias, quase sempre distanciadas das formas tradicionais de engajamento. Embora digam respeito sobretudo às sociedades ocidentais do Norte, as conclusões dos trabalhos de Ronald Inglehart sobre a posição dos valores nas mobilizações adotam um contexto analítico que também está muito presente a 
propósito da América Latina. ${ }^{35}$ Segundo ele, a característica essencial desses movimentos está na ênfase em valores como a identidade, o reconhecimento social, o respeito do indivíduo, os direitos humanos, as condições de vida, assim como na prioridade a reivindicações de participação na tomada de decisões. Enquanto as reivindicações materiais, particularmente a questão salarial, perderam em parte seu caráter central para essas mobilizações, estas contribuíram ao mesmo tempo para politizar a vida quotidiana e as relações sociais, transformando-as em objeto legítimo de demandas. Girando em torno de questões ligadas, por exemplo, à proteção do meio ambiente, ao gênero, às relações sexuais ou à moralidade, essas demandas remetem às questões diretamente políticas das liberdades de expressão e associação, do reconhecimento dos direitos sociais e da luta contra as discriminações.

Ronald Inglehart demonstrou assim que o ponto comum e a "novidade" desses movimentos sociais repousavam numa aspiração à construção de uma nova sociedade, na rejeição dos valores materiais associados à produção, à renda ou ao consumo e na afirmação de valores como a autonomia e as liberdades do indivíduo. Esses movimentos, de composição social heterogênea, ${ }^{36}$ foram cimentados por construções identitárias que pretenderam romper com as vinculações de classe, para conceder um espaço central a identidades transversais como o gênero, a cor da pele ou as práticas sexuais. Em torno dessas identidades, a busca da autoestima e da dignidade, assim como os discursos participativos, constituíram questões fundadoras do engajamento. ${ }^{37}$ De acordo com os trabalhos muito citados de Ronald Inglehart, a consolidação desses tipos de mobilização expressa a redefinição das clivagens fundamentais das sociedades contemporâneas. ${ }^{38}$ Ele também mostrou que a dimensão que opõe o materialismo ao pós-materialismo poderia explicar, a partir da década de 1960, a entrada na agenda política de novas questões, estando associada a realinhamentos partidários. Assim foi que Ronald Inglehart demonstrou de que maneira, na Europa ocidental, "a ascensão do pós-materialismo deixou os alinhamentos partidários sob tensão crônica", ${ }^{39} \mathrm{im}$ pondo uma reformulação dos sistemas partidários. Na América Latina, essa mudança apoiou-se na emergência de novos partidos social-democratas na década de 1980 e em sua consolidação na década de 1990. Com suas vitórias eleitorais da década de 2000, uma parte de seus dirigentes reafirmou seu compromisso com os valores que haviam fundado suas mobilizações das décadas anteriores, por exemplo, com a criação de instituições da democracia "participativa".

Em segundo lugar, os observadores da América Latina têm quase sempre frisado a estrutura heterogênea, instável e mesmo fluida das mobilizações populares, adotando um quadro analítico em parte construído a partir da Europa. ${ }^{40}$ Nas palavras de Alberto Melucci, assim, essas mobilizações ocasionaram a construção de amplos "espaços de movimento" no interior da "nebulosa de con- 
tornos imperfeitos" dos simpatizantes eventuais, muito mais ampla que o núcleo muito restrito dos ativistas engajados. ${ }^{41}$ Apoiada em organizações descentralizadas e flexíveis, a participação nos novos movimentos sociais apresentou um caráter cambiante, pouco homogêneo, muitas vezes informal ou descontínuo, sendo marcada pela rejeição dos sistemas dominantes de representação dos interesses. Esses movimentos sociais repousaram, assim, numa grande variedade de micro-organizações, associações de vizinhança, "unidades diversificadas e autônomas", de caráter "disperso, compósito, fluido", ocupando um espaço social "de limites incertos e densidade variável". ${ }^{42}$ Com base nas demandas às vezes extremamente localizadas formuladas por cada organização, assim como na circulação dos indivíduos e grupos no interior de redes entrecruzadas de mobilização, foi-se constituindo aos poucos um amplo "espaço de movimento". ${ }^{43}$

No interior desses espaços, constituídos de redes informais e fluidas ligando indivíduos e micro-organizações locais, as aproximações estratégicas ou a simples solidariedade mantiveram-se às vezes limitadas e mesmo problemáticas. De acordo com essa análise, a influência desse tipo de mobilização nos sistemas sociais e políticos foi exercida de maneira muito indireta, através da difusão aleatória de modelos de comportamento comuns ou de representações compartilhadas. Nessa perspectiva, Alberto Melucci definia os movimentos sociais, na década de 1980, como "sistemas de ação e de oportunidades, e campos de possibilidades e de limites". ${ }^{44}$ De maneira geral, por trás da coesão aparente de um movimento social, as motivações, as representações e os comportamentos coletivos são marcados pelo caráter heterogêneo e mesmo contraditório dos modos de ação política, em particular nos meios populares. ${ }^{45}$ Desse modo, a formatação política dessas ações não raro heteróclitas pode apresentar um caráter aleatório.

No que diz respeito à América Latina da década de 2000, onde, por exemplo, as mobilizações dos piqueteros argentinos remetem efetivamente a uma organização em "nebulosa", a questão da unificação do movimento social e de seu sentido político mantém-se atual. ${ }^{46}$ Denis Merklen mostrou que a heterogeneidade e a territorialização desse movimento se associam à difusão de um conjunto de representações e práticas políticas que delineiam uma nova "politicidade" das classes populares. ${ }^{47} \mathrm{O}$ movimento social extrai sua unidade, aqui, do fato de que indivíduos e grupos gravitam num mesmo sistema de ação, vale dizer, perseguem objetivos comuns, compartilham símbolos e mesmo a afirmação de uma identidade, e circulam num espaço militante partilhado. Apesar da fragmentação das organizações e símbolos, as trocas individuais e as convergências pontuais fundam, assim, uma unidade instável das representações e, ao mesmo tempo, das redes sociais de interação.

Se adotarmos essa perspectiva, as associações de bairros pobres do Brasil das décadas de 1980 e 1990 efetivamente foram constitutivas de um movimento social. Numa primeira análise, com efeito, chamam a atenção do observador a 
grande heterogeneidade dos modos de ação política de seus dirigentes, a ausência de unidade dessa nebulosa associativa, a impossibilidade de identificar seu impacto político. ${ }^{48} \mathrm{O}$ recurso ao conceito de "sistema de ação" permite, justamente, explicá-lo. Os vínculos interindividuais estabelecidos entre essas micro-organizações, sua representação comum de sua posição na cidade, os usos comuns dos discursos do direito e da justiça social ou ainda o recurso a um repertório de ação coletiva compartilhado permitem efetivamente falar aqui de um movimento social.

De maneira mais genérica, os movimentos sociais que se afirmaram na América Latina a partir do fim da década de 1970 foram apresentados como "novos" e comparados aos do Norte, em virtude de sua proximidade com o pós-materialismo e do recurso a discursos construídos em torno das demandas de dignidade e respeito, da recusa das discriminações e da invocação da "participação". Mas esses movimentos latino-americanos também se distinguiram por reivindicações prioritariamente concretas e materiais, pelo predomínio dos grupos populares e por seus efeitos limitados nos alinhamentos partidários até a década de $2000 .{ }^{49} \mathrm{O}$ ponto comum entre essas diferentes mobilizações sua estrutura e seu modo de organização - foi afinal considerado secundário para a construção das análises. De fato, a instabilidade, a fragmentação e a heterogeneidade dos movimentos latino-americanos foram sobretudo deploradas, sendo raramente observadas em termos de recursos, modos de ação ou oportunidades.

\section{A análise dos movimentos sociais: rumo a novas perspectivas de pesquisa?}

Muito citados na América Latina, os trabalhos de Jürgen Habermas e Alain Touraine marcaram profundamente as ciências sociais, particularmente a pesquisa sobre os movimentos sociais. Esta tem dado ênfase sobretudo à avaliação de seu potencial "transformador", à análise de sua relação com a estrutura social das economias dependentes e à de sua oposição aos aparelhos de Estado autoritários. Como observava em 1983 a socióloga brasileira Ruth Cardoso,

enquanto que os teóricos franceses, nossos inspiradores, falavam da mudança qualitativa das funções do Estado (...), nós, latino-americanos, para explicar fenômenos semelhantes, nos fixamos na crítica ao autoritarismo de nossos governos, deixando de lado as transformações substantivas do aparelho de Estado. ${ }^{50}$ 
Alain Touraine, por sua vez, duvidava da existência de "movimentos" urbanos, na medida em que não se apoiavam em nenhuma organização unitária, não participavam da construção de uma consciência de classe e portanto não podiam, segundo ele, promover uma mudança política profunda. ${ }^{51}$ Ao lado dessa reflexão sobre os limites da mudança política insuflada por esses movimentos, a pesquisa sobre os movimentos sociais organizou-se na América Latina em torno da questão da autonomia em relação às estruturas sociais e políticas do autoritarismo. E também foi com base nessa questão que ela buscou avaliar sua capacidade de mudar os sistemas políticos e as sociedades, e de construir espaços públicos democráticos.

\section{A questão da autonomia}

A repressão promovida pelos governos autoritários desde a década de 1960, o fim das guerrilhas castristas e a fragilização dos partidos comunistas não só deixaram um vazio político à esquerda como foram associados à desconfiança dos atores das mobilizações face aos corporativismos de Estado, aos populismos e, de maneira mais ampla, a qualquer tentativa de "instrumentalização". O conjunto levou as organizações de movimento social a apresentar a autonomia não só como uma estratégia mas também como um valor em si. Não raro hostis às organizações tradicionais de mobilização, em particular os sindicatos e os partidos políticos, os movimentos associativos valorizaram as organizações apresentadas como "comunitárias". Em grande medida, a sociologia política latino-americana apropriou-se então dessa questão. Em torno de uma atenção prioritária à relação entre movimentos sociais e instituições políticas, a autonomia veio a ser apresentada não só como uma especificidade dos "novos movimentos", como um objetivo colocado pelos atores, mas também como uma necessidade política. Em busca de um caminho alternativo entre autoritarismo, populismo e revolução, muitos analistas viram nos movimentos autônomos das sociedades civis uma fonte possível de inovação social. ${ }^{52}$ Três questões dominaram. Em primeiro lugar, a participação política foi objeto ao mesmo tempo de reivindicações dos movimentos sociais e de propostas de renovação da ação pública local. Em seguida, a vontade dos movimentos sociais de questionar as mediações tradicionais operadas pelos partidos e os sindicatos foi pensada como um fator necessário à democratização das práticas políticas. Finalmente, a organização dos movimentos sociais em bases locais reforçou os discursos sobre as "comunidades"; discursos disseminados ao mesmo tempo pelos atores locais, os poderes públicos em diferentes níveis e os observadores.

Segundo Ruth Cardoso, cuja análise parece-nos bastante representativa, a questão levantada por esses movimentos, na ausência de objetivo revolucioná- 


\section{Camille Goirand}

rio claro ou mesmo de reivindicações democráticas explícitas, não estava numa transformação radical dos sistemas políticos e das sociedades, mas no processo de inclusão política para os quais contribuíam: "por seu aspecto reivindicativo, os movimentos de bairro não parecem capazes de grandes transformações, mas se forem encarados como expressão de uma nova identidade, é possível pensar que se tornem uma nova peça no jogo político". 53

\section{As questões identitárias}

A avaliação da mudança introduzida pelos movimentos "de base" deu ênfase, portanto, à sua contribuição não em termos políticos, mas socioculturais. Sua inscrição no espaço das sociedades civis e sua autonomia frente aos poderes políticos foi portanto compreendida como decorrente de uma afirmação identitária, assim como de uma capacidade de inventar novas relações sociais na vida quotidiana. De acordo com as análises propostas por Willem Assies e Tillman Evers, por exemplo, esses "fragmentos de novas práticas sociais" participaram da construção de uma dignidade emancipada para as categorias populares, qualquer que fosse a fragilidade de suas organizações. "A essência desses movimentos está, em minha opinião, em sua capacidade de gerar uma nova subjetividade social: nova tanto por seu conteúdo quanto pela consciência de si mesma”, afirmava Tillman Evers. ${ }^{54}$ Por essa perspectiva, essas mobilizações se apoiaram na afirmação de um conjunto de valores novos em política, como a igualdade, a cidadania e a participação, apoiados na construção de uma autoestima para os participantes.

Enquanto os atores locais dos movimentos sociais quase sempre se recusavam a ir além de uma formulação extremamente imediata, concreta e territorializada de suas demandas, os observadores preferiram frisar seu conteúdo ético implícito, conjugado numa tripla demanda: reconhecimento da dignidade dos pobres, adoção de direitos sociais e participação cidadã. $O$ conjunto suscitou uma proliferação de discursos sobre a cidadania e a participação, apoiada numa sociologia do sujeito, que viu nos movimentos sociais "de base" um fator de afirmação dos pobres como "sujeitos" sociais autônomos e detentores de direitos.

Em 1994, por exemplo, Evelina Dagnino considerava que os novos movimentos sociais contribuíam para a "invenção de uma nova sociedade" e a construção de uma "nova concepção da cidadania", e que a afirmação do "direito de ter direitos" havia "servido de fundamento ao surgimento de um novo sujeito social (...) lutando pelo reconhecimento". ${ }^{55}$ Já em 1989 Eder Sader anunciava a entrada em cena de "novos sujeitos políticos" autônomos e independentes. ${ }^{56}$ 


\section{Movimentos sociais e espaço público}

Finalmente, nessa perspectiva, inspirada nos trabalhos de Jürgen Habermas, esses "novos" movimentos sociais são considerados participantes da democratização das sociedades, pois possibilitam a circulação de ideias no interior "de um espaço público não investido pelo poder", no qual as "práticas associativas formaram o substrato social da esfera pública" ${ }^{57}$ Evelina Dagnino, em seus trabalhos sobre a relação entre movimentos sociais e "sociedade civil", cidadania e "espaços públicos", descreve "a emergência de experiências de construção de espaços públicos", que se impuseram como "espaços de ampliação e democratização da gestão estatal". ${ }^{58}$ A construção de um espaço público democrático apoia-se aqui, portanto, numa gestão pública participativa que contribui para o "fortalecimento dos próprios atores da sociedade civil", através da instauração de espaços de "controle social do Estado", 59 que repousam na participação de setores da sociedade civil destituídos de outras formas de acesso aos espaços de decisão. Segundo Leonardo Avritzer, a consolidação das democracias latino-americanas apoiou-se na institucionalização de práticas sociais novas, introduzidas pelos novos movimentos sociais surgidos nas décadas anteriores, através da emergência da "política participativa". Desse modo, as associações voluntárias da sociedade civil introduzem novas práticas num espaço público em que a "deliberação pública" se institucionaliza. Se Leonardo Avritzer efetivamente frisa a ausência real de "transformação das práticas informais presentes na esfera pública em diferentes formas de democracia deliberativa", nem por isso deixa de considerar que "a democratização pode ser ampliada", graças a esses espaços públicos que permitiram uma "renovação política". ${ }^{60}$

O pluralismo social e a participação bastariam para garantir a democracia?... Em 1997, Jean Leca observava as dificuldades associadas a essas práticas deliberativas, assim como suas ambiguidades e mesmo seus riscos: "os grupos não representam uma prova maravilhosa da diversidade do social nem a expressão de uma ordem providencial. (...) O pluralismo funde o Estado e o social e os torna ingovernáveis, fragmentando cada um em constelações segmentadas de interesses". E acrescentava, com ironia: "tudo isso tem um certo lado 'conto de fadas', o que não chega a invalidá-lo". ${ }^{61}$ De fato, a abordagem dos movimentos sociais em termos de autonomia ou de transformação social, de afirmação identitária ou de democratização pela deliberação pública parece-nos apresentar certos riscos, relativos às interpretações a que dá lugar. Para formular de maneira simples, as abordagens apresentadas adiante parecem-nos estar mais ligadas à interpretação do sentido, isto é, a um posicionamento na cidade, do que a uma postura de pesquisa distanciada, que tivesse como prioridade observar relações de força e maneiras de fazer, além de contextualizá-las. 
É essa postura que explica que a queda de intensidade de certas mobilizações de rua, a partir de meados da década de 1990, tenha sido pensada como um "refluxo", e a aproximação com os partidos de esquerda, como uma perda de autonomia. ${ }^{62}$ Mas a observação também pode indicar que as mobilizações da década de 1970 nem sempre introduziram uma ruptura brutal nos sistemas políticos, construindo-se frequentemente em proximidade com as organizações militantes "clássicas". Com efeito, por trás das questões da autonomia e das identidades, é antes a hipótese de uma dinâmica de interações múltiplas entre os diferentes atores da "política contestatária" que pode ser confirmada, tanto pelos percursos individuais dos militantes quanto por sua multiposicionalidade ou pela convergência da contestação para certas organizações. ${ }^{63}$ A predominância das abordagens identitárias e culturais teve como consequência o fato de que outros processos foram pouco explorados, entre eles a profissionalização política dos militantes, dinâmicas organizacionais como o distanciamento entre dirigentes e simples participantes, as trajetórias de ascensão social dos militantes ou a desmobilização e os percursos de saída das organizações. ${ }^{64}$

Marcada pela pesquisa de uma "outra" democracia, entre liberalismo e marxismo, pela urgência da reflexão sobre os direitos e por uma forte tradição de intervenção política dos intelectuais, a sociologia latino-americana muitas vezes privilegiou essa abordagem interpretativa. De pouco tempo para cá, entretanto, abordagens diferentes parecem consolidar-se e completar as anteriores. Em 2003, por exemplo, Evelina Dagnino não frisava apenas os aspectos culturais das construções cidadãs, observando também o caráter estratégico dos discursos da cidadania. ${ }^{65}$ Trabalhos sobre a "construção" das identidades e mesmo sobre a invenção da memória e das origens indicam de que maneira elas estruturaram as estratégias de mobilização a partir da década de 1980. É, como demonstrou Jean-François Véran, o caso dos camponeses do interior do estado da Bahia, no Brasil, os quais, inicialmente mobilizados em sindicatos agrícolas, descobriram ser descendentes de negros mulatos na década de 1990, depois que a Constituição reconheceu um direito à propriedade da terra para essa categoria de população. Em 1995, as comemorações do tricentenário de morte de Zumbi dos Palmares conferiram uma mediatização e uma legitimidade inéditas às demandas de direitos desses camponeses pobres, fornecendo-lhes recursos maiores para suas mobilizações. Os camponeses bolivianos também entenderam o interesse que poderiam ter em mobilizar-se como índios, depois de várias décadas de mobilizações sindicais. ${ }^{66}$

\section{Movimentos sociais, partidos políticos e instituições}

Com efeito, se, por um lado, a autonomia dos novos movimentos sociais foi real, por outro, representou sobretudo uma situação temporária, ligada ao 
contexto bem específico e transitório criado pelas mudanças de regime político. Situadas fora dos contextos oferecidos pelas esquerdas revolucionárias fragilizadas, inexistentes ou desacreditadas, as mobilizações organizaram-se inicialmente fora das instituições políticas existentes, quando não em oposição a elas. Num ambiente ainda autoritário, mas já em processo de liberalização, os movimentos sociais permitiram a expressão de demandas sociais cuja mediação não podia ainda ser assegurada pelos sistemas de partidos em processo de construção. A criação de novos partidos políticos de esquerda, longe de representar uma perda de autonomia para esses movimentos sociais, apoiou-se em certos casos em sua iniciativa. A partir da década de 1980, a fábrica dos "partidos-movimentos", como no caso do PRD mexicano, do PT brasileiro, do Frente Amplio no Uruguai ou do MAS boliviano, permitiu a certos movimentos sociais passar à esfera política, fosse na qualidade de organizações, fosse através dos percursos individuais de seus militantes.

Ao longo da década de 2000, Doug McAdam, Sidney Tarrow e Charles Tilly propuseram a ampliação do campo de observação da sociologia das mobilizações, com base no conceito de "política contestatária" ou "política do conflito", que leva em conta as interações entre as esferas institucional e não-institucional, o entrecruzamento dos atores, das identidades e mobilizações, assim como os processos individuais de entrada e saída das organizações. ${ }^{67} \mathrm{~A}$ ação coletiva inscreve-se portanto num continuum, ao mesmo tempo em termos de redes sociais e de relação entre instituições, e em termos históricos. Partidos e organizações "amigas" formam assim um "espaço de mobilização" de contornos sociais nebulosos, constituído por redes militantes, nas quais circulam os indivíduos. Assim foi que, em sua pesquisa sobre o Partido da Revolução Democrática (PRD) no México, Hélène Combes mostrou que a criação desse partido em 1989 apoiou-se na aproximação de atores militantes, provenientes de organizações diversas: “mais que por difusão territorial, o PRD construiu-se por 'agregação' territorial em torno de organizações sociais, que se transformaram em verdadeiras estruturas de enquadramento dos militantes". ${ }^{68}$ Desse modo, os militantes provenientes de organizações contestatárias representaram na década de 1990 uma proporção considerável dos membros desse partido. Segundo a autora, ao ser criado o PRD, apenas um quarto dos seus dirigentes não tinha militado no período anterior. A proporção de militantes provenientes dos movimentos sociais aumentou até 1994, quando representava a metade dos dirigentes do partido. Posteriormente, a organização, abalada por intensas lutas de facções, procurou reforçar sua coesão, por exemplo com a introdução de eleições internas, com o objetivo de fazer com que "o partido ganhasse corpo". ${ }^{69}$

Sob muitos aspectos, a construção do Partido dos Trabalhadores, no Brasil, seguiu modalidades comparáveis à do PRD. Convergência de múltiplas 
organizações de movimento social e pequenos partidos de extrema esquerda transformados em "tendências" em seu interior, o PT foi marcado em seus 20 primeiros anos por grandes dificuldades de unificação de estratégias, discursos e organização. Esse partido não tem origem na cisão do único partido de oposição tolerado pelo regime militar até a reintrodução do multipartidarismo em dezembro de 1979 , mas num projeto político pensado como novo. ${ }^{70}$ Rejeitando um retorno ao sistema partidário do período republicano dos anos 1945 a 1964, os fundadores do PT buscaram traduzir na ação política as reivindicações pluralistas dos sindicatos independentes surgidos das greves de 1978 e 1979, assim como reunir atores que haviam entrado para a política no período autoritário. Concebido mais como um meio estratégico de unir as oposições do que como um instrumento de mediação das demandas, esse partido foi pensado por seus fundadores como um recurso necessário para unir movimentos fragmentados e transpor sua luta para o campo político. Nossas pesquisas em nível local, no estado brasileiro de Pernambuco, confirmam que a fundação do PT efetivamente seguiu um processo de "agregação territorial" comparável ao mencionado por Hélène Combes a respeito do PRD..$^{71}$ Tendo chegado ao partido pelas mobilizações sociais, muitos membros do PT preservaram um duplo engajamento ao longo de sua vida militante. No caso dos sindicalistas metalúrgicos, do setor bancário e da companhia regional de hidroeletricidade, a $\mathrm{CHESF},{ }^{72}$ o militantismo partidário enraizou-se em mobilizações conduzidas no meio profissional, contando, para sua organização, com recursos fornecidos pelos sindicatos, em termos de adesões, logística e legitimidade. De maneira mais ampla, observa-se que a organização do PT refletiu nos primeiros anos o engajamento sindical prioritário dos membros, por sua estruturação em "núcleos" implantados nos locais de trabalho. Desse modo, a fundação do PT no início da década de 1980 é relembrada por esses sindicalistas como uma maneira de "ir mais longe", ou seja, por um lado, de fortalecer a mobilização no local de trabalho, mediante reivindicações políticas de caráter mais geral, e, por outro, de investir as instituições representativas para aumentar os recursos disponíveis à ação coletiva. A esse respeito, as hipóteses da "multiposicionalidade" dos militantes e do "continuum" da ação coletiva explicam as estratégias dos movimentos sociais "de base", assim como as trajetórias de seus militantes. Sugerem também que a questão da autonomia tem menos a ver com a estratégia histórica das organizações contestatárias do que com discursos, sejam eruditos ou militantes.

\section{Agenda de pesquisa: trajetórias, configurações e continuidades}

A partir de meados da década de 1990, os observadores dos movimentos sociais latino-americanos ficaram impressionados não só com a queda de inten- 
sidade das mobilizações mas também com os consideráveis limites de suas conquistas. De fato, a instauração de governos representativos não se apoiou, em termos imediatos, numa democratização profunda das sociedades, cada vez mais violentas e calcadas na desigualdade. ${ }^{73}$ Uma vez atendidas suas demandas materiais, as micro-organizações locais surgidas na década de 1980 perderam em muitos casos sua capacidade de reivindicação e mobilização. Esse processo de desmobilização pode ser explicado por diferentes fatores, que pudemos, de nossa parte, observar nas favelas do Rio de Janeiro. Para começar, a satisfação de certas demandas materiais, expressa por exemplo na ideia de que "agora temos tudo"... Depois, também, um certo cansaço e desânimo, associado à vontade de se dedicar mais aos interesses privados. ${ }^{74} \mathrm{~A}$ partir de um trabalho de pesquisa quantitativa sobre a produção documental das organizações de movimento social no Brasil, Ana Maria Doimo mostrou que a década de 1990 fora palco de um número menor de mobilizações que a década anterior. ${ }^{75}$ Frente a essa erosão, observadores, intelectuais e universitários de esquerda manifestaram desencanto e desilusão proporcionais às expectativas que haviam projetado, anos antes, nas mobilizações populares. Frisando seus fracassos e suas fragilidades, muitos deles lastimaram os limites da mudança social imposta pelo "movimento popular" (no singular), afinal efêmero e marcado pelo "paroquialismo". ${ }^{76}$ Apresentada como uma perda de autonomia e de identidade, e mesmo como um compromisso, a institucionalização dos novos movimentos sociais foi interpretada, assim, como um fracasso.

O "refluxo" dos novos movimentos sociais, portanto, fez correr muita tinta a partir do meado da década de 1990. Apesar de pertinente no que diz respeito à queda de intensidade de certas mobilizações contestatárias surgidas na década de 1980, essa análise nem por isso deixa de ser incompleta, por duas razões pelo menos. Primeiro, porque está calcada na ideia de uma oposição radical entre movimentos sociais e política institucional, que não leva em conta os resultados de trabalhos clássicos sobre a participação política ${ }^{77}$ nem a "complementaridade do protesto e da ação política convencional", tal como mencionada por exemplo por Jack Goldstone. ${ }^{78}$ Depois, porque um olhar na direção das trajetórias individuais dos militantes e dos espaços sociais e políticos por elas percorridos permite nuançar o diagnóstico do "refluxo" ou do fracasso. Ele indica em que medida o ciclo de protesto surgido na década de 1980, por um lado, possibilitou a formação de um novo pessoal político e administrativo, ${ }^{79} \mathrm{e}$, por outro, permitiu o reconhecimento de certos direitos fundamentais. Além disso, a década de 2000 mostrou que esse ciclo de protesto certamente não estava encerrado.

Note-se que o sentido adquirido pela institucionalização dos movimentos sociais surgidos na década de 1970 não é unívoco. No que diz respeito às associações de bairro, por exemplo, duas interpretações entram em concorrência. A 
primeira frisa o caráter pouco ou nada politizado, volátil e heterogêneo dessas micro-organizações, voltadas prioritariamente para o atendimento das demandas materiais localizadas, em exclusivo benefício de seus membros. Nessa perspectiva, institucionalização pôde significar clientelização e mesmo desmobilização. Por outro lado, essas organizações inserem-se num sistema de ação amplo, construído pela intensa circulação de seus militantes e suas diferentes posições, entre movimento social, partidos políticos, administrações públicas locais e profissões de assistência social. De outra parte, Sydney Tarrow mostrou que os ciclos de protesto começam, mas também prosseguem, com mudanças na estrutura das oportunidades políticas. Segundo ele, o fim dos ciclos de protesto é marcado por recomposições da política institucional e notadamente pela integração dos dirigentes dos grupos contestatários aos sistemas políticos, ${ }^{80}$ já que seu novo posicionamento não os impede automaticamente de conservar suas antigas lealdades militantes. Jack Goldstone considera, assim, que "entender de que maneira os movimentos sociais dão origem a partidos, delineiam os alinhamentos políticos e interagem com as instituições da política 'normal', tudo isso é essencial para compreender as dinâmicas políticas". 81

Na América Latina da década de 2000, as vitórias eleitorais de partidos de esquerda construídos na contestação desde a década de 1980 inscrevem-se num tal processo. ${ }^{82} \mathrm{Na}$ realidade, as dinâmicas dessas recomposições são múltiplas. Em primeiro lugar, muitas demandas dos movimentos populares foram incluídas nas agendas políticas nacionais, sendo objeto, hoje, de políticas públicas. É o caso, por exemplo, das reivindicações indigenistas nos países andinos, que em todos os casos adotaram novas constituições nas décadas de 1990 e 2000 e reconheceram o caráter "multicultural" de suas nações. ${ }^{83}$ Em segundo lugar, considerável número de militantes provenientes dos movimentos populares entrou para a política. Dois antigos sindicalistas famosos dirigem atualmente a Bolívia e o Brasil. Em nível local, os dirigentes dos partidos de esquerda podem contar, no exercício de seus mandatos legislativos, com forte enraizamento nos meios associativos e sindicais ${ }^{84}$ Em terceiro lugar, uma parte dos dirigentes associativos conseguiu converter as competências adquiridas na mobilização em recursos profissionais, por exemplo em administrações municipais de esquerda. $\mathrm{Na}$ cidade brasileira de Recife, dirigida desde 2001 pelo PT, são numerosos os antigos militantes associativos integrados aos serviços municipais encarregados da habitação social, do desenvolvimento urbano e da elaboração participativa do orçamento. Por fim, em todo o continente, a generalizada introdução de políticas municipais ditas "participativas" inscreve-se igualmente nessa dinâmica de recomposição, já que institucionalizou novos canais de mediação das demandas sociais e acentuou a rotineirização dos movimentos. Entretanto, ainda são insuficientes as pesquisas sobre a maneira como esses dispositivos de participação e consulta contribuem para transformar lógicas do poder local e abrem novos es- 
paços para a ação política. De forma mais geral, as dinâmicas da mobilização transitam por essas reconfigurações das relações de força locais, por essa dupla história em que as construções institucionais convergem com as trajetórias individuais; dinâmicas cuja observação, em nível local, ainda está por fazer.

Desde o início da década de 2000, as mobilizações desenrolam-se num ambiente renovado, que oferece múltiplos recursos às organizações de ação coletiva. Em primeiro lugar, não obstante os limites dos processos de democratização, os sistemas políticos nacionais mostram-se mais favoráveis à expressão de suas reivindicações e à mediação de suas demandas, como vimos. Além disso, os movimentos surgidos desde a década de 1970 inserem-se cada vez mais em redes transnacionais que contribuem para sua legitimação, a difusão de suas palavras de ordem e a construção de alianças em diferentes níveis. ${ }^{85}$ Para observar essas mobilizações, parece indispensável não mais se limitar à avaliação do impacto, da contribuição ou do sentido da contestação, recorrendo a outros instrumentos conceituais e metodológicos da sociologia da ação coletiva: não só a identificação dos recursos e estratégias mobilizadas pelos atores, a observação das práticas da contestação, a análise das lógicas das organizações, como também um olhar na direção das trajetórias militantes, da reconstituição do espaço social e político ocupado pelos movimentos - perspectivas necessárias para renovar nossa abordagem dos movimentos sociais da América Latina.

\section{Notas}

1. Ver, por exemplo, Timothy Wickham-Crowley (1991: 82-109).

2. Essa estratégia se apoia na construção e na participação em "transnational issue networks", analisados por Margareth Keck e Kathryn Sikkink (1998: 89-ss).

3. Para uma enumeração mais sistemática das características apresentadas por esses "novos movimentos sociais", ver Maria da Glória Gohn (1997: 121-170).

4. É o que Norbert Lechner já indicava, por exemplo, na década de 1980 (cf. Lechner, 1988).

5. Bert Klandermans (1986: 13-37).
6. Temos em mente em particular os trabalhos de Mancur Olson ou J. G. March e Herbert Simon sobre a ação coletiva e as organizações.

7. Em especial: Anthony Oberschall (1973), John D. MacCarthy e Mayer N. Zald (1977: 1.212-1.241) e Charles Tilly (1978).

8. Ronald Inglehart (1977) e Alberto Melucci (1985: 789-816).

9. É assim que Maria da Glória Gohn (1997) estrutura seu manual.

10. A partir da década de 1980, muitos trabalhos sobre essa questão foram realizados, dando origem a publicações 
comparativas de grande alcance. Por exemplo: Sonia Alvarez e Arturo Escobar (1992). Os trabalhos publicados fora da América Latina adotaram abordagens perfeitamente comparáveis, notadamente David Slater (1985), seguido de dois dossiês da revista Latin American Perspectives (vol. 21, $\mathrm{n}^{\circ} 2$ e 3, 1994) também dirigidos por esse autor.

11. No caso da França, essa questão foi abordada, por exemplo, por Martine Barthélémy (2000) e Jacques Ion (1997). Em terreno bem diferente, foi igualmente o que pudemos constatar no Rio de Janeiro na década de 1990. Ver Camille Goirand (2000).

12. Vale registrar algumas exceções, como por exemplo o trabalho de Paulo da Costa Neves (1999).

13. Willem Assies (1994: 81-105) mostra de que maneira as abordagens das mobilizações se estruturaram em torno desse conceito de "movimento popular". Na medida em que levam em conta a composição social e as demandas das mobilizações, essas definições são mais restritivas que as propostas, por exemplo, por François Chazel em 1992. Ele definia um "movimento social" como um "empreendimento coletivo de protesto e contestação visando a impor mudança - de importância variável - na estrutura social e/ou política mediante recurso frequente - mas não necessariamente exclusivo - a meios não-institucionalizados" (Chazel, 1975: 502- 516).

14. Sobre esse aspecto das transições democráticas, ver, por exemplo, Juan Rial (1991: 303-319) e Guillermo O’Donnell, Philip Schmitter e Laurence Whitehead (1986).

15. A este respeito, ver a tese de Julie Devineau (2008).

16. Ver Salvador Martí y Puig (2004). O conceito de "transição insurgente" foi trabalhado por Elizabeth Wood (2000).

17. Anthony Oberschall (1973: 77).
18. David Snow et al. (1986: 464) mostraram que os membros de um movimento social efetuam um trabalho de definição de uma situação, que em parte repousa em sua interpretação como inaceitável, contestável, injusta: "conferindo sentindo a acontecimentos, os estados de espírito permitem organizar a experiência e orientar a ação, seja individualmente seja coletivamente".

19. Renato Boschi (1987). Sobre o conceito de "quadro de injustiça", ver William Gamson et al. (1982).

20. As leis do "ponto final" (1986) e da "obediência devida" (1987) significaram uma anistia, já que puseram fim à perseguição dos autores de violações dos direitos humanos do período autoritário (1973-83).

21. Sobre os feminismos e os direitos reprodutivos, ver Bérengère Marques-Pereira e Florence Raes (2002: 17-36). Sobre o movimento contra a fraude eleitoral no México, ver Hélène Combes (2004, cap. 1). Para um amplo panorama das mobilizações da década de 1980, ver Susan Eckstein (2001a).

22. Em nossas próprias pesquisas sobre o percurso individual dos dirigentes associativos no Rio de Janeiro e posteriormente dos militantes do Partido dos Trabalhadores no Nordeste do Brasil, constatamos a frequência da socialização política no interior das organizações católicas, como a Pastoral das Favelas e a Pastoral Rural, na década de 1970. Para uma comparação do papel desempenhado pela Igreja católica nos diferentes países, ver Daniel Levine e Scott Mainwaring (2001: 203-239).

23. "O processo de ressocialização empreendido pelas CEB serviu de base a motivações que promoveram a ação e a consciência democrática entre os dirigentes de bairro" (Krischke, 1991: 193). 
24. Para uma análise comparada da passagem dos corporativismos de Estado a sistemas pluralistas, ver Philip Oxhorn (1998: 195-217) e Steven Levitsky e Scott Mainwaring (2006: 21-42). Esses autores consideram que entre 1985 e 1995 as principais organizações sindicais do continente perderam entre 25 e $75 \%$ dos filiados.

25. Susan Eckstein (2001: cap. 1).

26. David Slater (1994: 11-37).

27. Para um apanhado geral sobre as mobilizações na década de 2000, ver Susan Eckstein (2001: 351-406). Ver também o dossiê The New Politics of Social Movements in Latin America (2007).

28. Denis Merklen (2002: 143-164).

29. Acordo de Livre Comércio das Américas.

30. Denis Merklen (2006: 173-197).

31. A este respeito, ver Sophie Daviaud (2006).

32. Ver Christian Gros (2001: 147-159).

33. Para uma análise comparada desse processo de institucionalização e suas consequências nas mobilizações, ver Donna Lee Van Cott (2005).

34. É o caso, por exemplo, de Luis D'Elia, dirigente da FTV, uma das principais organizações piqueteras argentinas, que aceitou o cargo de subsecretário de Estado para a Terra e a Habitação Social no primeiro governo Kirchner.

35. Ronald Inglehart (1984: 25-69).

36. As pesquisas efetuadas por Ronald Inglehart indicam claramente que os grupos que defendem os valores pósmaterialistas são majoritariamente formados por indivíduos que sempre desfrutaram de segurança física e econômica. À luz dessa constatação, as clivagens verificadas em certos movimentos sociais latino-americanos encontram um pri- meiro fator de explicação. Por exemplo, no contexto dos feminismos, é evidente a oposição entre as posições defendidas pelas mulheres de categorias médias e superiores, efetivamente ligadas a esse "pósmaterialismo", e as demandas formuladas pelos grupos provenientes das classes populares, muito mais materiais e imediatas. Distinguimos, por exemplo, a defesa da paridade em política e a luta contra as discriminações de gênero, por um lado, e, por outro, as demandas de melhora dos cuidados maternos e infantis ou dos sistemas de guarda de filhos. Ver Bérengère Marques-Pereira e Florence Raes (2002).

\section{Claus Offe (1985: 817-868).}

38. Segundo ele, "o fato de esses movimentos terem ocupado o centro da cena na política contemporânea reflete uma evolução de longo prazo nas prioridades das populações ocidentais em termos de valores" (Inglehart, 1984: 26).

39. Ronald Inglehart (1984: 68).

40. Sobre a influência predominante dos modelos de análise construídos na Europa, ver Maria da Glória Gohn (1997: 214-218).

41. Esta expressão é tomada de empréstimo a Alberto Melucci (1983). O conceito de espaço de movimento foi retomado e aprofundado por Lilian Mathieu (2002: 75-100).

\section{Alberto Melucci (1983).}

43. Segundo essa perspectiva, o espaço de movimento "engloba não só as organizações 'formais' mas também a rede de relações 'informais' que interliga os indivíduos do centro e os grupos ao espaço mais amplo dos participantes e 'usuários' de serviços e bens culturais produzidos pelo movimento" (Melucci, 1983).

44. Para Alberto Melucci, ainda, "o que se costuma chamar empiricamente de 'movimento social' é um sistema de ação, que 
interliga orientações e significados plurais" e mesmo divergentes (Melucci, 1985: 789-816).

45. É o que pudemos constatar nos subúrbios do Rio de Janeiro, na década de 1990 (Goirand, 2000: caps. 9 e 10).

46. A propósito desse movimento, ver Maristella Svampa e Sebastián Pereyra (2003).

47. Denis Merklen (2006). Por "politicidade", o autor designa formas de ação coletiva estabelecidas pelas classes populares, representando ao mesmo tempo estratégias de sobrevivência, contestação das instituições e da classe política e participação política democrática.

48. Camille Goirand (2000).

49. É o que ressalta de várias publicações recentes sobre as esquerdas na América Latina: dossiê Gauches de gouvernement, gauches de rejet, Problèmes d'Amérique Latine, n. 55, inverno de 2004-2005, e dossiê Etat des lieux des gauches en Amérique Latine, Revue internationale de politique comparée, 12(3), 2005.

50. Ruth Cardoso (1983: 219).

51. Alain Touraine (1985: 769-787).

52. A exemplo de Judith Hellman (1992:

52-61) e também de Eder Sader (1991).

53. Ruth Cardoso (1983: 238).

54. Tillman Evers (1985: 67).

55. Evelina Dagnino (1994: 103-115; 2003: 3-17).

56. Eder Sader (1991). Até hoje, as análises em termos de sujeito, identidade e cultura mantêm-se muito presentes, como na análise proposta por Alicia C. S. Swords (2007: 78-93), ou ainda em Manuel Antonio Garretón (2002: 7-24).

57. Jürgen Habermas (1993: XXXI).
58. Evelina Dagnino (2002).

59. Evelina Dagnino (2002: 10-11).

60. Leonardo Avritzer (2002: 5-8).

61. Jean Leca (1996: 223).

62. "Os movimentos de base podem desaparecer de cena - e é muitas vezes o caso - enquanto atores autônomos uma vez que deem seu apoio, se aliem formalmente ou, de uma forma ou de outra, entreguem seu destino nas mãos dos partidos políticos", estimava também Judith Hellman (1992: 59).

63. Ver Doug MacAdam, Sidney Tarrow e Charles Tilly (2001).

64. Para uma perspectiva comparada, ver os trabalhos reunidos por Olivier Fillieule (2005).

65. Sem chegar a falar de um recurso, ela considera que "a referência à cidadania proporcionou um fundamento comum e um princípio de articulação a uma imensa diversidade de movimentos sociais”, para os quais ela constituiu "um instrumento útil” e "um poderoso vínculo" (Dagnino, 2003: 3-4).

66. Jean-François Véran (2003) e JeanPierre Lavaud (2005: 105-128).

67. Doug MacAdam, Sidney Tarrow e Charles Tilly (2001) e Charles Tilly e Sidney Tarrow (2008).

68. Hélène Combes (2006 : 151).

69. Hélène Combes (2004: 237-240 e 340).

70. Sobre a criação desse partido, ver Margareth E. Keck (1986-87: 67-95); sobre a trajetória percorrida por certos dirigentes da oposição legal ao regime militar, ver as entrevistas publicadas por Marieta de Moraes Ferreira et al. (2001).

71. Para esta pesquisa no Nordeste brasileiro, foram associadas entrevistas semidiretivas, consulta de arquivos e observação. 
72. Companhia Hidroelétrica do São Francisco.

73. É o que mostram os trabalhos publicados em Juan E. Mendel, Guillermo O’Donnell e Paulo Sérgio Pinheiro (2000).

74. É o que mostramos em La politique des favelas (Goirand, 2000: cap. 6).

75. Ana Maria Doimo (1995: cap. 4).

76. Pedro Jacobi (1990: 34-44).

77. Eles indicam que os indivíduos engajados também são os que apresentam maior propensão a participar da política convencional. Eles indicam que os indivíduos engajados também são os que apresentam maior propensão a participar da política convencional.

78. Jack A. Goldstone (2003: 7).

79. Problèmes d'Amérique Latine publicou um dossiê sobre o tema: Le renouvellement du personnel politique, n. 59, inverno de 2005-2006.

Referências bibliográficas

ALVAREZ, Sonia \& ESCOBAR, Arturo (dir.). The Making of Social Movements in Latin America: Identity, Strategy and Democracy. Boulder (Col.): Westview Press, 1992.

ASSIES, Willem. Urban Social Movements in Brazil: A Debate and its Dynamics. Latin American Perspectives, 21 (2), 1994, p. 81-105.

AVRITZER, Leonardo. Democracy and Public Space in Latin America. Princeton-Oxford: Princeton University Press, 2002.
80. Sidney Tarrow (1994, cap. 1)

81. Jack A.Goldstone (2003: 12).

82. Olivier Dabène (2007); Revue Internationale de Politique Comparée, dossiê Etat des lieux des gauches en Amérique Latine, 2005.

83. Christian Gros (2003: 11-29).

84. No que diz respeito ao PT na região Nordeste, são questões de que tratamos em "Pratiques partisanes et loi électorale au Brésil" (Goirand, 2007: 41-77).

85. Kathryn Sikkink (2005: 151-173) propõe a respeito um modelo de análise a partir da observação das mobilizações em torno da justiça transicional na Argentina e na Espanha. Sua perspetiva é enriquecida de maneira interessante, a partir de um estudo de caso por Julie Stewart (2004: 259-278).

BARTHELEMY, Martine. Les associations: un nouvel âge de la participation? Paris: Presses de Sciences Po, 2000.

BOSCHI, Renato. $A$ arte da associação: política de base e democracia no Brasil. São Paulo: Vértice-Iuperj, 1987.

CARDOSO, Ruth Corrêa Leite. Movimentos sociais urbanos: um balanço crítico. In: SORJ, Bernardo \& ALMEIDA, María Hermínia Tavares de (eds.). Sociedade e política no Brasil pós-1964. São-Paulo: Brasiliense, 1983. 
CHAZEL, François. La mobilisation politique: problèmes et dimensions. Revue Française de Science Politique, 25 (3), 1975, p. 502-516.

COMBES, Hélène. De la politique contestataire à la fabrique partisane. Le cas du PRD au Mexique (1989-2000). Tese orientada por O. Dabène - IHEAL, Paris, 2004.

. Des militants par intermittence? Le PRD au Mexique (1989-2000). Critique Internationale, janeiro de 2006.

DABENE, Olivier (ed.). Amérique Latine, les élections contre la démocratie? Paris: Presses de Sciences Po, 2007.

DAGNINO, Evelina. Os movimentos sociais e a emergência de uma nova noção de cidadania. In:- (ed.). Anos 90, política e sociedade no Brasil. São Paulo: Brasiliense, 1994, p. 103-115.

Sociedade civil e espaços públicos no Brasil. São Paulo: Paz e Terra, 2002.

Citizenship in Latin America. Latin American Perspectives, 30 (2), n. 129, março de 2003, p. 3-17.

DAVIAUD, Sophie. Droits de l'homme et politique. L'enjeu des droits fondamentaux dans le conflit colombien. Tese (Doutorado) orientada por Daniel Pécaut - EHESS, Paris, 2006.

DEVINEAU, Julie. Les mutations de l'Etat territorial: décentralisation, mobilisations et politiques indigènes au Mexique, 1970-2004. Tese (Ciência Política) orientada por Richard Balme - IEP, Paris, 2008. 446 p.

DOIMO, Ana Maria. A vez e a voz do popular: movimentos sociais e participação política no Brasil. Rio de Janeiro: Relume-Dumará, 1995.

Dossiê Etat des lieux des gauches en Amérique latine. Reoue Internationale de Politique Comparée, 12 (3), 2005.
Dossiê Gauches de gouvernement, gauches de rejet. Problèmes d'Amérique Latine, n. 55, inverno de 2004-2005.

Dossiê Le renouvellement du personnel politique. Problèmes d'Amérique Latine, n. 59, inverno de 2005-2006.

Dossiê The New Politics of Social Movements in Latin America. Latin American Perspectives, 34 (2), n. 153, março de 2007.

ECKSTEIN, Susan (ed.). Power and Popular Protest. Latin American Social Movements. Berkeley: California University Press, 2001a.

. Where Have All the Movements Gone? Latin American Social Movements at the New Millenium. In: Power and Popular Protest. Latin American Social Movements. 2a ed. Berkeley: California University Press, 2001b, p. 351-406.

EVERS, Tillman. Identity: The Hidden Side of New Social Movements in Latin America. In: SLATER, David (ed.). New Social Movements and the State in Latin América. Amsterdam: CEDLA, 1985.

FERREIRA, Marieta de Moraes et al. Vozes da oposição. Rio de Janeiro: FGV, 2001.

FILLIEULE, Olivier (dir.). Le désengagement militant. Paris: Belin, 2005.

GAMSON, William et al. Encounters with Unjust Authorities. Homewood (Ill.): The Dorsey Press, 1982.

GARRETON, Manuel Antonio. La transformación de la acción colectiva en América Latina. Revista de la CEPAL, Santiago, n. 76, abril de 2002, p. 7-24.

GOHN, Maria da Glória. Teorias dos movimentos sociais: paradigmas clássicos e contemporâneos. São Paulo: Loyola, 1997.

GOIRAND, Camille. La politique des favelas. Paris: Karthala, 2000.

Pratiques partisanes et loi électorale au Brésil. In: DABENE, Olivier (ed.). 
Amérique Latine, les élections contre la démocratie? Paris: Presses de Sciences Po, 2007, p. 41-77.

GOLDSTONE, Jack A. Bridging Institutionalized and Noninstitutionalized Politics. In: - (ed.). States, Parties and Social Movements. Cambrigde: Cambridge University Press, 2003.

GROS, Christian. Métissage et identité. La mosaïque des populations et les nouvelles demandes éthniques. Pouvoirs, Paris, n. 98, 2001, p. 147-159.

. Demandes ethniques et politiques publiques en Amérique latine. Problèmes d'Amérique Latine, n. 48, primavera 2003, p. 11-29.

HABERMAS, Jürgen. L'espace public: archéologie de la publicité comme dimension constitutive de la société bourgeoise. Paris: Payot, 1993.

HELLMAN, Judith. The Study of Social Movements in Latin America and the Question of Autonomy. In: ALVAREZ, Sonia \& ESCOBAR, Arturo (eds.). The Making of Social Movements in Latin America: Identity, Strategy, and Democracy. Boulder (Col.): Westview Press, 1992, p. 52-61.

INGLEHART, Ronald. The Silent Revolution. Changing Values and Political Styles among Western Publics. Princeton: Princeton University Press, 1977.

- The Changing Structure of Political Cleavages in Western Society. In: DALTON, Russel; FLANAGAN, J. Scott C. \& BECK, Paul Allen (eds.). Electoral Change in Advanced Industrial Democracies: Realignment or Dealignment? Princeton (NJ): Princeton University Press, 1984, p. 25-69.

ION, Jacques. La fin des militants. Paris: L'Atelier, 1997.
JACOBI, Pedro. Movimentos sociais urbanos: os desafios da construção da cidadania. Cadernos do CEAS, n. 129, 1990, p. 34-44.

KECK, Margareth. Democratization and Dissension: The Formation of the Workers' Party. Politics and Society, 15 (1), 1986-87, p. 67-95.

KECK, Margareth \& SIKKINK, Kathryn. Activists Beyond Borders: Advocacy Networks in International Politics. Ithaca: Cornell University Press, 1998.

KLANDERMANS, Bert. New Social Movements and Resource Mobilization: The European and the American Approach. International Fournal of Mass Emergencies and Disasters, 4(2), agosto de 1986, p. 13-37.

KRISCHKE, Paulo. Church Base Communities and Democratic Change in Brazilian Society. Comparative Political Studies, 24 (2), julho de 1991, p. 193.

LAVAUD, Jean-Pierre. Démocratie et éthnicisation en Bolivie. Problèmes d'Amérique Latine, n. 56, primavera de 2005, p. 105-128.

LECA, Jean. La démocratie à l'épreuve des pluralismes. Revue Française de Science Politique, 46 (2), abril de 1996, p. 223.

LECHNER, Norbert. Los patios interiores de la democracia: subjetividade y política. Santiago: Facultad Latinoamericana de Ciencias Sociales, 1988.

LEVINE, Daniel \& MAINWARING, Scott. Religion and Popular Protest in Latin America: Contrasting Experiences. In: ECKSTEIN, Susan (ed.). Power and Popular Protest. Latin American Social Movements. Berkeley: California University Press, 2001, p. 203-239.

LEVITSKY, Steven \& MAINWARING, Scott. Organized Labor and Democracy in Latin America. Comparative Politics, 39 (1), 2006, p. 21-42. 
MacADAM, Doug, TARROW, Sidney \& TILLY, Charles. Dynamics of Contention, Cambridge: Cambridge University Press, 2001.

MacCARTHY, John D. \& ZALD, Mayer N. Resource Mobilization and Social Movements: a Partial Theory. The American Fournal of Sociology, 82 (6), maio de 1977, p. 1.212-1.241.

MARQUES-PEREIRA, Bérengère \& RAES, Florence. Trois décennies de mobilisations féminines en Amérique latine. Cahiers des Amériques Latines, Paris, n. 39, 2002, p. 17-36.

MARTÍ Y PUIG, Salvador. Tiranías, rebeliones y democracia. Itinerarios políticos comparados en Centroamérica. Barcelona: Bellaterra, 2004.

MATHIEU, Lilian. Rapport au politique, dimensions cognitives et perspectives pragmatiques dans l'analyse des mouvements sociaux. Revue Française de Science Politique, fevereiro de 2002, p. 75-100.

MELUCCI, Alberto. Mouvements sociaux, mouvements post-politiques. Revue Internationale d'Action Communautaire, 10 (50), outono, 1983, p. 13-30.

. The Symbolic Challenge of Contemporary Movements. Social Research, 52 (4), inverno, 1985, p. 789-816.

MENDEL, Juan E.; O'DONNELL, Guillermo \& PINHEIRO, Paulo Sérgio (eds.). Democracia, violência e injustiça. O Não-Estado de Direito na América Latina. São Paulo: Paz e Terra, 2000.

MERKLEN, Denis. Le quartier et la barricade: le local comme lieu de repli et base du rapport au politique dans la révolte populaire en Argentine. L'Homme et la Société, n. 143-144, 2002, p.143-164.

- Une nouvelle politicité pour les classes populaires. Les piqueteros en Argen- tine. Tumultes, Paris, n. 27, novembro de 2006, p. 173-197.

NEVES, Paulo da Costa. L'action syndicale des travailleurs du pétrole à Bahia, Brésil. Pétrole, nationalisme et politique. Tese orientada por Jean Bunel - Universidade de Lyon 2, Paris, 1999.

O'DONNELL, Guillermo; SCHMITTER, Philip \& WHITEHEAD, Laurence (eds.). Transitions from Authoritarian Rule, Prospects for Democracy, 4 vols. Baltimore: John Hopkins University Press, 1986.

OBERSCHALL, Anthony. Social Conflict and Social Movements. Englewood Cliffs (NJ): Prentice-Hall, 1973.

OFFE, Claus. New Social Movements: Challenging the Boundaries of Institutional Politics, Social Research, 52 (4), 1985, p. 817-868.

OXHORN, Philip. Is the Century of Corporatism Over? Neoliberalism and the Rise of Neopluralism. In: OXHORN, Ph. \& DUCATENZEILER, G. (eds.). What Kind of Democracy? What Kind of Market? Latin America in the Age of Neoliberalism. University Parc (Pen.): The Pennsylvania State University Press, 1998, p. 195-217.

RIAL, Juan. Les transitions en Amérique latine au seuil des années quatre-vingt-dix. Rezue Internationale des Sciences Sociales, $\mathrm{n}$. 128 , maio de 1991, p. 303-319.

SADER, Eder. Quando novos personagens entraram em cena: experiências, falas e lutas dos trabalhadores da Grande São Paulo (1970-80). Rio de Janeiro: Paz e Terra, 1991.

SIKKINK, Kathryn. Patterns of Dynamic Multilevel Governance and the InsiderOutsider Coalition. In: DELLA PORTA, Donatella \& TARROW, Sidney (eds.). Transnational Protest and Global Activism. Rowman and Littlefield: Lonham, 2005, p. 151-173. 
SLATER, David (dir.). New Social Movements and the State in Latin América. Amsterdam: CEDLA, 1985.

\section{- Power and Social Movements in the Other Occident, Latin America in an International Order. Latin American Perspectives, 21 (2), n. 81, primavera, 1994, p.11-37.}

SNOW, David et al. Frame Alignment Processes, Micromobilization, and Movement Participation. American Sociological Review, n. 51, 1986.

STEWART, Julie. When local troubles become transnational: the transformation of a Guatemalan indigenous rights movement. Mobilization, 9 (3), outubro de 2004, p. 259-278.

SVAMPA, Maristella \& PEREYRA, Sebastián. Entre la ruta y el barrio. La experiencia de las organizaciones piqueteras. Buenos Aires: Biblios, 2003.

SWORDS, Alicia C. S. Neo-Zapatista Network Politics. Transforming Democracy and Development. Latin American Perspectives, 34 (2), março de 2007, p. 78-93.

TARROW, Sydney. Power in Movement. Social Movements, Collective Action and Politics. Cambridge: Cambridge University Press, 1994.
TILLY, Charles. From Mobilization to Revolution. Reading: Addisson-Wesley, 1978.

TILLY, Charles \& TARROW, Sidney. Politique(s) du conflit. De la grève à la révolution. Paris, Presses de Sciences Po, 2008.

TOURAINE, Alain. An Introduction to the Study of Social Movements. Social Research, inverno, 52 (4), 1985, p. 769-787.

. Existe-t-il des mouvements urbains. In: La parole et le sang. Paris: Odile Jacob, 1988.

VAN COTT, Donna Lee. From Movements to Parties in Latin America. The Evolution of Ethnic Politics. Cambridge (NY): Cambridge University Press, 2005.

VERAN, Jean-François. L'esclavage en héritage (Brésil). Le droit à la terre des descendants de marrons. Paris: Karthala, 2003.

WICKHAM-CROWLEY, Timothy. A Qualitative Approach to Latin American Revolutions. International fournal of Comparative Sociology, 32 (1-2), abril de 1991, p. 82-109.

WOOD, Elisabeth. Forging Democracy from Below: Insurgent Transitions in South Africa and El Salvador. Nova York: Cambridge University Press, 2000.

\section{Resumo}

A análise das mobilizações a partir da categoria "novos movimentos sociais", construída na Europa, continua sendo dominante na abordagem dos movimentos latino-americanos. Este artigo lembra, na sua primeira parte, as especificidades dos movimentos "de base" nascidos durante os anos 1970 na América Latina. Em seguida, mostra as diferenças entre os debates e as abordagens das mobilizações, de um continente para o outro. Quando, sobre a América Latina, se insistiu muito sobre os valores, as mudanças culturais e as identidades, nos Estados Unidos o enfoque foi para a análise das organizações, das estratégias e das práticas. A terceira parte do artigo mostra as 
consequências dessa divergência científica para a observação dos processos de institucionalização dos movimentos sociais, assim como para a análise da contestação na América Latina nos anos 2000.

Palavras-chave: movimentos sociais, teorias da ação coletiva, América Latina

\begin{abstract}
The analysis of social mobilizations as "new social movements", a category built in Europe, has been dominant in the approach of Latin-American movements. This article recalls in its first part the specificities of "base movements" born in Latin America during the 1970's. Then it shows the debates and the different approaches of social mobilizations. While, in Latin America, the emphasis was put on values, cultural changes and identities, in the United States it was put on the analysis of organizations, strategies and practices. Finally the third part shows the consequences of this scientific divergence on the observation of the institutionalization processes of social movements, as well as on the analysis of opposition in Latin America in the years 2000.
\end{abstract}

Key words: social movements, theories of collective action, Latin America

\title{
Résumé
}

L'analyse des mobilisations à partir de la catégorie "nouveaux mouvements sociaux", d'abord construite en Europe, continue à être dominante pour l'approche des mouvements latino-américains. Cet article rappelle, dans sa première partie, les spécificités des mouvements "de base" nés durant les années 1970 en Amérique latine. Ensuite, il montre les différences qui existent dans les débats ainsi que dans les approches des mobilisations, d'un continent à l'autre. A propos de l'Amérique latine, on a beaucoup insisté sur la question des valeurs, des changements culturels et des identités, alors qu'aux Etats-Unis l'accent était mis sur l'analyse des organisations, des stratégies et des pratiques. La troisième partie de l'article montre les conséquences de cette divergence scientifique pour l'observation des processus d'institutionnalisation des mouvements sociaux, ainsi que pour l'analyse de la contestation en Amérique latine dans les années 2000. Mots-clés: mouvements sociaux, théories de l'action collective, Amérique latine 